\title{
Designing and Validating Teachers' Professional Development Scale: Iranian EFL Contexts in Focus
}

\section{Leila Saberi}

Department of English, Marvdasht Branch, Islamic Azad University, Marvdasht, Iran, saberi500@yahoo.com

\section{Rahman Sahragard}

Prof., Shiraz University, Iran, rahman.sahragard@ gmail.com

The issues and the underlying motives behind second / foreign language teachers' professional development have been increasingly investigated by the experts and practitioners in the field due to its vital role in determining teachers' success. In line with such concerns, the current study was conducted to explore the underlying factors constituting the newly developed teachers' professional development scale. It also intended to find the professional development factors that Iranian EFL teachers use to enhance teaching effectiveness. 142 Iranian male and female practicing teachers were conveniently selected to cooperate in this study. They were asked to answer the 18- item Likert scale questionnaire and express their attitude about the contributing factors. Three sources of evidence were used to support the validity of the questionnaire including content validity, reliability coefficient, and factor analysis. The result of exploratory factor analysis depicted that this questionnaire consists of two underlying components: self- regulation and other-regulation components. It was also realized that Iranian EFL teachers tend to rely more on their own experiences and capacities rather than external guide and support in their professional development. Further research can focus on qualitative data collection procedures such as interviewing teachers in order to realize their views toward the factors that help them develop professionally.

Keywords: professional development, validation, factor Analysis, self-regulation, otherregulation

\section{INTRODUCTION}

One of the main goals of language teaching is to facilitate students' learning. In order to fulfil this aim, teachers need to have various kinds of knowledge and skills to build and keep effective teaching conditions. Therefore, teachers' professional knowledge may be called as one of most important characteristics in instruction. Elbaz (1983, p.11)

Citation: Saberi, L., \& Sahragard, R. (2019). Designing and Validating Teachers' Professional Development Scale: Iranian EFL Contexts in Focus. International Journal of Instruction, 12(1), 16091626. https://doi.org/10.29333/iji.2019.121102a 
believed that "the single factor which seems to have the greatest power to carry forward our understanding of the teacher's role is the phenomenon of teachers' knowledge". Yandell (2017) argued knowledge is born from social engagement; therefore, conceptualizing knowledge as the possession of the teachers, to be transferred to teachers, is misleading. The issue of teachers' knowledge and the nature of their professional development process which have been considered as important issues have emerged as critical concerns of research in the field of language teacher professionalism during the last few years. Atay (2006) believed that the concept of teachers' professional learning in all fields of pedagogies is so important that many researchers have put fingers on, in their studies. In fact, a growing recognition has occurred related to the attention paid by educators to the significant role of teachers in students' achievement. Desimone, Smith, and Ueno (2006) reported that professional development is viewed as a necessary mechanism that can deepen teachers' content knowledge and enhance their teaching practices. In the same vein, Richards and Farrell (2005) stated, everything around English teachers is changing; therefore, developing teachers professionally is absolutely necessary. They further emphasized that professional development of teachers directly influences their teaching and thus the learning of the students.

It is vital to point out the importance of affording the practitioners the ability to identify their own professional development requirements, as they are the professionals at the interface between teachers and learners. The professional development of teachers is a key to students' learning in the context of English as a foreign language. As a field within the educational domain, it has many unique characteristics that separate it from other venues of teaching. First and foremost, EFL teachers work in an environment where the means of instruction is also the subject of instruction. They practice their craft in a variety of instructional environments and as a result, often teach in isolation from other educators. In fact, it can be said that the opportunities for teachers' professional development are sparse.

There is, however a dearth of empirical and conceptual studies found in the literature that actually define the professional development unique to EFL teachers. Given the increasing population of students studying English as a foreign language (EFL) in Iran, it is not surprising that EFL teaching is a growing field in this country. With this in mind, the primary purpose of this study is to examine teachers' professional needs, and the contributing factors in this regard. This investigation seems quite necessary for developing more effective teaching and learning contexts.

Considering the relevant literature, it seems that few studies on EFL teachers' professional development in Iran. In fact, only few attempts have been made in order to develop or design a model specifically suitable for this context. Studies of this kind can pave the ground to put forward a new scale that is richly contextualized in practice. Investigating the prevalent conceptualizations related to teachers' professional development, the existing model is intended to be revitalized based on societal and educational realities which have not been truly addressed in teacher education and its connected issued including teachers' professional development. 


\section{LITERATURE REVIEW}

\section{Elements for Professional Development in Education}

Related to the initial preparatory stages taken by Avalos (2011), Guskey and Yoon (2009), in their paper, provided three shared common elements for professional growth which was the result of nine well-designed investigations reviewed by researchers in the field: a) Workshops: Among all the professional development activities, workshops have been greatly disesteemed in recent years, especially those of short duration. In fact, many education leaders criticize workshops and consider them as the waste of both time and money. Workshops can be wasteful if they are not followed with sustained assist. But a number of studies have shown a positive relationship between professional development and progress in student learning following workshops. These workshops have emphasized the enforcement of research-based instructional practices in a way that teachers can adapt the practices to their own classroom context b) Outside Experts: Many scholars in education today believe that one of the most effective ways to bring progress is to have educators in each school with a regular visit in order to explore common problems and find solutions based on shared experiences and collective wisdom. But while this might be considered as a suitable starting point, it is seldom, if ever, enough (Karimi, 2011; Desimone \& Stuckey, 2014; Cordingley, 2007). c) Time: This is the third element introduced by Guskey and Yoon (2009). They argued:

Professional development advocates have long lamented the lack of sufficient time for staff members to engage in high-quality professional learning. Obviously, educators need time to deepen their understanding, analyse students' work, and develop new approaches to instruction. But simply providing more time for professional development yields no benefit if that time is not used wisely (p. 496).

In a similar vein, Yurtsever (2013) asserted that the concept of teacher professionalism in education has been scrutinized in connection with many other variables, such as teachers' gradual change throughout their experiences. Guskey (2000) asserted that these characteristics were not what many would have proposed and vary from those factors frequently mentioned as contributing to the productivity of professional development endeavours. Ninlawn (2015) believed that factors like creative and innovative skills, communication and media awareness, computer, and information technology have a positive effect on teachers' professional development concerning the development of courses and resources. Rastegar, Bagheri, Sadighi, and Yarmohammadi (2015) specified that factors like a) learning/goal orientation, which is teachers' pursuing a goal, especially a learning goal, b) teacher self-efficacy, that is teachers' beliefs in their own abilities, c) professional commitment, that is when teachers love teaching, d) organizational climate, that is how teachers experienced the immediate teaching environment, and e) learning organization culture, that is teachers' ongoing learning, can all promote teachers' professional development. Evers, Kreijns, and Van der Heijden (2016) stated that among the factors that can affect teachers' professional development, organizational factors like learning climate, and social support from colleagues can act as the positive resources. 
Concerning the effect of different factors on teachers' professional development, Richards (2011) investigated ten key dimensions of language teaching expertise and growth in order to plan for the professional development English language teachers. He emphasized teachers' language proficiency factor which is related to their ability to accomplish aspects of a lesson fluently and comprehensively in English. This is specially an important competence for those whose mother tongue is not English. Teachers with low level of proficiency are more dependent on teaching resources like textbooks and less likely to become creative (Miller, 2006). The roles of content knowledge and contextual knowledge have also been emphasized by Richards (2011). He stated that related to the question of what language teachers need to know in order to reach their full potential as language teachers has led the curricula of M.A. programs to offer courses such as language analysis, learning theory, methodology, and sometimes a teaching practicum. The part of teachers' knowledge which is the practical side, however, was undervalued in teacher education programs. Regarding contextual knowledge, Richards $(2011$, p.4) truly asserted that "learning is situated; that is, it takes place in specific settings or contexts that shape how learning takes place. Language teachers teach in many different contexts, and in order to function in those contexts they need to acquire the appropriate contextual knowledge"'.

Fundamental teaching skills considered as the primary challenge for novice teachers and English teachers' identity have also been accentuated by in Richards' paper (2011). Do English teachers really know what it means to be a language teacher? Identity refers to enactment of different social and cultural roles by teachers and learners throughout their interactions while engaged in learning process. Such roles are dynamic and appear in the social context of the classroom.

Seeking a departure from teacher-fronted paradigms, Richards (2011) believed that although teaching can be regarded as a kind of teacher performance, the main objective behind teaching is to assist students' learning, therefore, learner-centeredness can be considered as a characteristic of expert teachers. Instead of emphasizing teacher' speech in the classroom, learners' input should be encouraged. Borg's (2006) review of the characteristics of expert teachers can be listed as follows:

a) Being familiar with individual student behaviors.

b) Using their knowledge of learners in order to predict what may happen in the classroom.

c) Building their lessons based on students' difficulties.

d) Encouraging students' involvement in the classroom to keep them active.

Constructing a personal system of knowledge, beliefs, and understandings that rises out of practical experience of teaching and being an active member of the professional community were also highlighted as important dimension of teaching determining to a large extent the success and effectiveness of teaching. According to Richards (2011):

Viewing language teaching as a private activity is a narrow and self-centred view of teaching that fails to capitalize on the potential for learning and growth that comes from participating in a community of teachers having shared goals, values, and 
interests. The teaching context becomes a learning community, and its members constitute a community of practice. A community of practice has two characteristics: 1. it involves a group of people who have common interests and who relate and interact to achieve shared goals. 2. It focuses on exploring and resolving issues related to the workplace practices that members of the community take part in (p.7)

Pedagogical reasoning skills which are among the ten core dimensions for language teachers conceived by Richards (2011), refer to the way English teachers' beliefs, thoughts, and thinking processes form and direct not only their understanding of teaching but also their classroom practices and teachers' professionalism. In fact, it can be said that teaching entails a specialized knowledge base gained through both academic study and practical experience.

The ten core dimensions examined and elaborated by Richards (2011) were considered in the design and specification of items in the professional development scale validated in the study.

\section{Research Aim}

The purpose of this study was to explore the underlying factors of the teachers' professional development questionnaire, and find the factors used by EFL teachers as a way to improve them professionally. Specifically, this study had the following objectives:

1. What are the underlying factors constituting the newly designed teachers' professional development scale?

2. What professional development factors do Iranian EFL teachers use to enhance their teaching effectiveness?

\section{METHOD}

\section{Research Design}

This was a questionnaire design in which the process of designing the format and questions in the survey instrument was used to collect data. In order to answer the research questions, a Professional Development Questionnaire was developed and used. Factor analysis was conducted and the components building the questionnaire were extracted. Participants' answers were also investigated to find out the extent to which they had used the factors included in the questionnaire to develop their professional skills as an EFL teacher according to the specified continuum.

\section{Participants}

This research used convenient sampling through which 142 Iranian male and female practicing teachers were selected to cooperate in this study. As factor analysis was needed in this study, the researcher tried to increase the number of participants to the extent possible.

1. As university-based teacher education was the primary concern of the study, the teachers with no academic experience were eliminated to conduct the study only with those who had passed the courses in language teaching at the MA level.

2. Consulting the experts in the field, teachers with at least 4 years or 2000 hours teaching experience were considered to be experienced teachers. Prospective 
teachers are then those who have just passed courses in MA with little teaching experience.

3. The participants were selected from Shiraz and Abadeh Azad universities, Fars Research and Science University, Yasuj Research and Science University, Shiraz University, and Qeshm International branch of Shiraz University for some kind of "location triangulation" (Brown, 2002) to control for the differential effects due to particular academic situations in different universities.

4. Factor analysis was used to check the construct validity of the newly developed questionnaire, so the researcher tried to select a large sample to ensure the suitability of data for factor analysis. Tabachnick and Fidell (2007) asserted that a sample at least as small as 150 cases may be sufficient. Dorney (2010) was less conservative to claim that a minimum of 100 (but preferably more) subjects is needed for factor analysis. As Pallant (2013) indicated, the ratio of respondents to items is the main concern rather than the overall sample size. The consensus in the field is that five respondents for each item are enough in most cases.

\section{Data Collection Instrument}

Based on the literature on second language and foreign language teacher education, EFL teachers' professional development, Kumaravadivelu's modular model (2012), and also interviews with some EFL educators who had the experience of teaching courses at MA and BA programs, the researcher designed and developed a questionnaire called Professional Development Questionnaire (PD) with 18 items in a Likert Scale. In so doing, the first draft of the questionnaire was revised and re-worded a number of times considering the expert' comments. The next step was a pilot study which again resulted in eliminating and re-wording some of the items. To assure that the data collection procedure brings about accurate data, reliability coefficient was computed. To calculate the reliability, Cronbach Alpha index was used. As the results showed, the questionnaire enjoyed a high rate of reliability, .838. Factor analysis was also performed to decide on the construct validity of the questionnaire.

\section{Data Collection Procedure}

Group, one to one, and E-mail administrations were used to collect the data. Care was taken to give clear written instructions in the questionnaire. However, as it was realized, through a pilot study, that some respondents answered the PD questionnaire based on the perceived usefulness of the items rather than their actual experiences, the researcher, before administering the questionnaire, tried to provide the respondents with some explanations about the aim of the study to avoid the possible ambiguities. The respondents were given about 10 minutes to answer the questionnaire.

\section{Data Analysis Procedure}

In this study, three main sources of evidence were used to support the validity of the questionnaire. In order to examine the content validity of the questionnaire, ten experts were asked to review each item of the questionnaire closely. The items which were rejected by more than three of the judges were eliminated from the pool of items. The resulting items were included in the questionnaire distributed for pilot study. Three EFL 
teachers answered the questionnaire for the pilot study. At the end, the teachers were asked to comment on the items by indicating the questions which were somehow ambiguous. The professors' comments based on the pilot study were observed by the expert group and the necessary revisions were made. This part guarantees the content validity of the study.

Moreover, reliability coefficient was calculated using Cronbach Alpha. This is the scale which is used to measure reliability of the questionnaire. The result is provided in the following sections. Furthermore, factor analysis was used to measure the construct validity of the questionnaire. By applying principle component analysis, the main components of the questionnaire were extracted. A descriptive analysis of the answers provided for each item of the questionnaire is presented in the result section. Before running the aforementioned statistical procedures, however, the researcher considered the following issues:

1. The initial data file was checked to see if there are any mistakes made by the respondent when filling in the questionnaire. This procedure is referred to as data cleaning.

2. Changes in the dataset were also checked prior to the analyses to determine if any slight changes were necessary in order to make the data more appropriate for the statistical procedures and avoid bias. This procedure is referred to as data manipulation.

\section{Content Validity}

In order to validate the questionnaire, the researcher requested thirty-two participants to fill out the questionnaire and provide comments and technical details to construct a more valid questionnaire. The respondents offered some detailed comments about the appearance and the content of the questionnaire. This trial run showed that the initial version of the questionnaire functioned as intended. A revised version of the questionnaire was developed after the analysis of the participants' responses and comments. Accordingly, some refinements were made. The above pieces of information taken from the pilot study provided the evidence for the content validity of this questionnaire. However, the following sections on reliability and construct validity of the teaching style questionnaire were carried out independently by the researcher for the sake of this study.

\section{FINDINGS}

To develop and validate the PD questionnaire, the following procedures were followed. The first draft of this scale consisted of 23 items which after content validation, expert judges, and piloting reduced to18 items. Some modifications were also applied in the wordings of items to avoid ambiguity. The procedures for its reliability estimates and construct validation were as follows:

Step 1: Calculating the reliability of the scale using Cronbach alpha measures

Step 2: Checking item-total statistics to determine the impact of deleting each item on the final reliability value 
Step 3: Recalculating reliability of the scale with 16 items maintained

Step 4: Measuring the appropriateness of the data for principal component analysis via correlation matrix, KMO, and Bartlett's Test.

Step 5: Checking the table of total variance explained for determining the components whose eigenvalues are above 1. (4 components had eigenvalue above 1)

Step 6: Using component and patters matrix to notice item loading below each component

Step 7: Checking the scree plot (a break was noticed after the second and the third components)

Step 8: Calculating parallel analysis (2 eigenvalues were larger than the criterion value from parallel analysis)

Step 9: Running factor analysis with 2 components specified

Step 10: Running factor analysis with 3 components specified

Step 11: Comparing the three-pattern matrix obtained from steps six, nine, and ten to determine the item loadings that best describe variance in the data

Out of 142 responses to the scale, 108 were considered as appropriate for further analysis. Table 1 shows the number of respondents.

Table 1

Number of participants

\begin{tabular}{llll}
\hline & & $\mathrm{N}$ & $\%$ \\
\hline \multirow{3}{*}{ Cases } & Valid & 108 & 100.0 \\
\cline { 2 - 4 } & Excluded & 0 & .0 \\
\cline { 2 - 4 } & Total & 108 & 100.0 \\
\hline
\end{tabular}

Table 2 provides information about the internal consistency of the questionnaire.

Table 2

Reliability statistics

\begin{tabular}{lll}
\hline $\begin{array}{l}\text { Cronbach's } \\
\text { Alpha }\end{array}$ & $\begin{array}{l}\text { Cronbach's Alpha Based on } \\
\text { Standardized Items }\end{array}$ & $\begin{array}{l}\text { N of } \\
\text { Items }\end{array}$ \\
\hline .838 & .840 & 18 \\
\hline
\end{tabular}

This table shows that the reliability of the questionnaire is .838 which suggests very good reliability for the scale with this sample. Item-total statistics was also inspected to see if deleting some items remarkably increases the reliability of the whole scale. 
Table 3

Item-total statistics

\begin{tabular}{clllll}
\hline & $\begin{array}{l}\text { Scale Mean if } \\
\text { Item Deleted }\end{array}$ & $\begin{array}{l}\text { Scale Variance if } \\
\text { Item Deleted }\end{array}$ & $\begin{array}{l}\text { Corrected Item- } \\
\text { Total Correlation }\end{array}$ & $\begin{array}{l}\text { Squared Multiple } \\
\text { Correlation }\end{array}$ & $\begin{array}{l}\text { Cronbach's Alpha } \\
\text { if Item Deleted }\end{array}$ \\
\hline item1 & 60.32 & 101.586 & .105 & .103 & .845 \\
\hline item2 & 60.21 & 100.132 & .141 & .187 & .845 \\
\hline item3 & 58.96 & 95.457 & .508 & .561 & .827 \\
\hline item4 & 59.90 & 91.382 & .481 & .333 & .827 \\
\hline item5 & 59.29 & 94.300 & .483 & .545 & .828 \\
\hline item6 & 59.84 & 90.134 & .604 & .601 & .821 \\
\hline item7 & 59.94 & 89.810 & .604 & .503 & .820 \\
\hline item8 & 60.94 & 96.707 & .282 & .316 & .838 \\
\hline item9 & 60.58 & 93.161 & .398 & .379 & .832 \\
\hline item10 & 59.40 & 95.812 & .374 & .322 & .833 \\
\hline item11 & 59.75 & 92.694 & .534 & .502 & .830 \\
\hline item12 & 59.33 & 96.243 & .434 & .365 & .827 \\
\hline item13 & 59.49 & 93.972 & .482 & .331 & .825 \\
\hline item14 & 59.83 & 91.355 & .527 & .383 & .828 \\
\hline item15 & 59.94 & 94.080 & .465 & .485 & .829 \\
\hline item16 & 59.51 & 94.439 & .450 & .432 & .825 \\
\hline item17 & 59.61 & 92.445 & .532 & .436 & .830 \\
\hline item18 & 59.65 & 95.576 & .431 & .428 & \\
\hline
\end{tabular}

Table 3 reveals that items one and two have low item- total correlation (below.3) and deleting them can increase the reliability of the questionnaire to .845 which is quite high. Thus, they were eliminated from the scale as they were most probably measuring something different from the whole scale. Table 4 confirms an increase in reliability after items $1 \& 2$ were deleted. The items deleted were:

1. The courses I've passed at BA

2. The courses I've passed at MA

Table 4

Reliability statistics

\begin{tabular}{lll}
\hline $\begin{array}{l}\text { Cronbach's } \\
\text { Alpha }\end{array}$ & $\begin{array}{l}\text { Cronbach's Alpha Based on } \\
\text { Standardized Items }\end{array}$ & N of Items \\
\hline .845 & .856 & 16 \\
\hline
\end{tabular}

All the 3 pieces of evidence required confirmed the suitability of running factor analysis with the sample. There were few correlations below .3 in the correlation matrix and Table 5 shows that KMO is above .6 (.773) and Bartlett's test is significant at .000 value.

Table 5

KMO and Bartlett's test

\begin{tabular}{llr}
\hline Kaiser-Meyer-Olkin Measure of Sampling Adequacy. & .773 \\
\hline Bartlett's Test of Sphericity & Approx. Chi-Square & 579.712 \\
\cline { 2 - 3 } & Df & 153 \\
\cline { 2 - 3 } & Sig. & .000 \\
\hline
\end{tabular}


According to Kaiser's (1960) criterion-requiring the components to have eigenvalues above one, the first four components have eigenvalues above 1 and therefore appropriate for further analysis. Table 6 shows that the first 4 factors' eigenvalues are $5.180,1.751,1.277$, and 1.059 respectively. This criterion, however, is not dependable without considering the scree plot and parallel analysis.

Table 6

Total variance explained

\begin{tabular}{lllllll}
\hline Component & \multicolumn{2}{l}{ Initial Eigenvalues } & \multicolumn{3}{c}{ Extraction Sums of Squared Loadings } \\
\cline { 2 - 7 } & Total & \% of Variance & Cumulative \% & Total & \% of Variance & Cumulative \% \\
\hline 1 & 5.180 & 32.372 & 32.372 & 5.180 & 32.372 & 32.372 \\
\hline 2 & 1.751 & 10.943 & 43.315 & 1.751 & 10.943 & 53.315 \\
\hline 3 & 1.277 & 7.982 & 51.297 & 1.277 & 7.982 & 57.914 \\
\hline 4 & 1.059 & 6.617 & 57.914 & 1.059 & 6.617 & \\
\hline 5 & .985 & 6.158 & 64.072 & & & \\
\hline 6 & .833 & 5.208 & 69.280 & & & \\
\hline 7 & .723 & 4.520 & 73.800 & & & \\
\hline 8 & .660 & 4.125 & 77.924 & & & \\
\hline 9 & .637 & 3.980 & 81.904 & & & \\
\hline 10 & .617 & 3.854 & 85.759 & & & \\
\hline 11 & .568 & 3.547 & 89.306 & & & \\
\hline 12 & .459 & 2.869 & 92.175 & & & \\
\hline 13 & .408 & 2.550 & 94.724 & & & \\
\hline 14 & .374 & 2.338 & 97.062 & & & \\
\hline 15 & .244 & 1.525 & 98.588 & & & \\
\hline 16 & .226 & 1.412 & 100.000 & & & \\
\hline
\end{tabular}

In Figure 1 a mild break is observed after the second and third components indicating that retaining both two and three components can be true. However, one should not limit his analysis to the scree plot test and two other pieces of evidence need to be determined: parallel analysis and pattern matrix. Table 7 depicts the results parallel analysis calculated using the software online. It can be observed from the table that the first two components initial eigenvalues (Table 6) are larger than the random eigenvalues reported in the output from parallel analysis (Table 7).

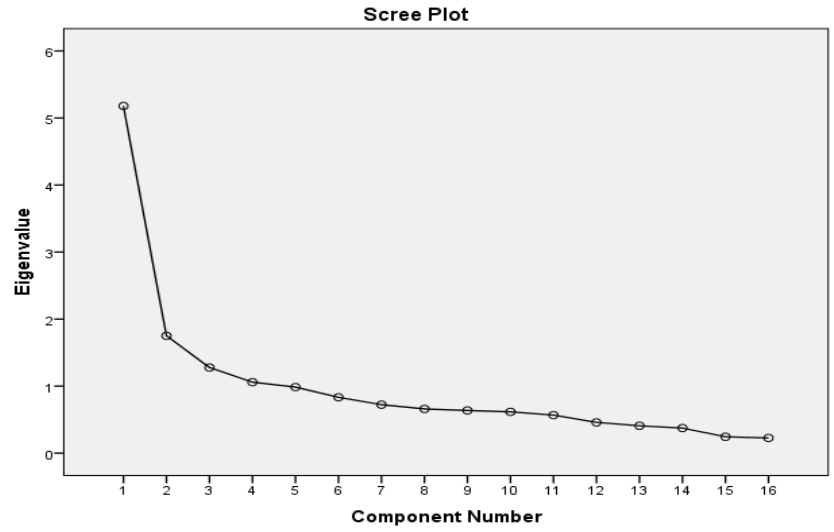

Figure 1

Scree Plot 
Table 7

Monte Carlo PCA for parallel analysis

\begin{tabular}{lcc}
\hline \multicolumn{4}{l}{ Eigenvalue \# Random Eigenvalue } & Standard Dev \\
\hline 1 & 1.7750 & .0800 \\
\hline 2 & 1.6348 & .0697 \\
\hline 3 & 1.5020 & .0518 \\
\hline 4 & 1.3945 & .0529 \\
\hline 5 & 1.2901 & .0458 \\
\hline 6 & 1.2089 & .0385 \\
\hline 7 & 1.1260 & .0409 \\
\hline 8 & 1.0590 & .0344 \\
\hline 9 & 0.9949 & .0354 \\
\hline 10 & 0.9211 & .0342 \\
\hline 11 & 0.8563 & .0338 \\
\hline 12 & 0.7909 & .0345 \\
\hline 13 & 0.7285 & .0338 \\
\hline 14 & 0.6675 & .0341 \\
\hline 15 & 0.6080 & .0301 \\
\hline 16 & 0.5483 & .0331 \\
\hline 17 & 0.4853 & .0361 \\
\hline 18 & 0.4090 & .0361 \\
\hline
\end{tabular}

Version 2.5

Number of variables: 18

Number of subjects: 108

Number of replications: 100

In order to decide to retain either 2 or 3 factors, the researcher also compared the item loadings in the pattern matrix obtained from 2 principal component analysis, one with 2 factors maintained and the other with 3 . Tables 8 and 9 show the item loadings on 2 and 3 components maintained.

Table 8

Pattern matrix for item loadings on two components

\begin{tabular}{llc} 
& \multicolumn{2}{c}{ Component } \\
\cline { 2 - 3 } & 1 & 2 \\
\hline item6 & .760 & \\
\hline item7 & .681 & \\
\hline item9 & .672 & \\
\hline item11 & .637 & \\
\hline item17 & .561 & \\
\hline item14 & .556 & \\
\hline item4 & .544 & \\
\hline item15 & .523 & \\
\hline item8 & .487 & \\
\hline item3 & & .798 \\
\hline item5 & & .764 \\
\hline
\end{tabular}




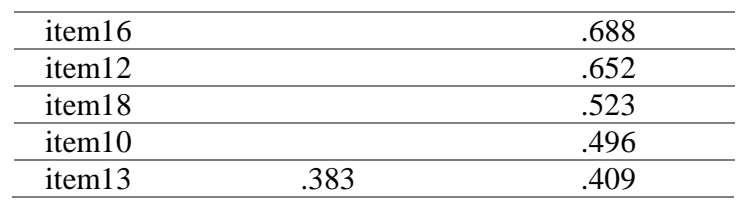

Table 9

Pattern matrix for item loadings on three components

\begin{tabular}{llll}
\hline \multicolumn{5}{c}{ Component } \\
\hline item6 & .817 & 3 \\
\hline item7 & .711 & \\
\hline item11 & .708 & & \\
\hline item17 & .657 & & \\
\hline item14 & .612 & & \\
\hline item4 & .552 & .783 & \\
\hline item15 & .493 & .760 & \\
\hline item3 & & .658 & \\
\hline item5 & & .606 & \\
\hline item16 & & .566 & \\
\hline item12 & & .521 & \\
\hline item10 & & & \\
\hline item18 & & & \\
\hline item13 & .319 & & \\
\hline item8 & & & \\
\hline item9 & .416 & \\
\hline
\end{tabular}

Table 9 reveals that less than 3 items are loaded on component 3 and retaining it does not seem adequate. Thus, it was finally concluded that the scale consists of two subscales: factor 1 and factor 2 .

Factor 1: item4, item6, item7, item8, item9, item11, item14, item15, and item 17

$>$ Item 4: In-service teacher training programs (TTC)

$>$ Item 6: Observers' feedback

$>$ Item 7: Asking colleagues for help

$>$ Item 8: Checking relevant research findings in the journals

$>$ Item 9: Attending workshops and conferences

$>$ Item 11: Institutional teaching tips, rules and regulations

$>$ Item 14: Teachers' book

$>$ Item 15: Peer coaching

> Item 17: Classroom observation

Factor 2: item3, item5, item16, item12, item18, item10, item13

$>$ Item 3: Teaching experiences inside the class

Item 5: My own reflections on issues and challenges I have faced in the class

$>$ Item 16: Self-critical evaluation

$>$ Item 12: Materials and textbooks I've taught 
$>$ Item 18: Learners overall attitude toward the nature and scope of classroom events and activities

$>$ Item 10: My own experiences as a learner

$>$ Item 13: Learners' feedback

Based on the commonalities of items loaded on the 2 factors, the following names are chosen for them:

Factor 1: Other -regulation

Factor 2: Self -regulation

The means for each of the factors above are calculated to see how much each factor has been used by Iranian EFL teachers during their professional career in Iran as an EFL context. Using the compute section in SPSS, the items in each factor are averaged. Table 10 shows the descriptive statistics for the 2 components extracted.

Table 10

Descriptive statistics

\begin{tabular}{|c|c|c|c|c|c|c|c|c|c|}
\hline & & \multicolumn{5}{|c|}{ Paired Differences } & \multirow[t]{2}{*}{$\mathrm{t}$} & \multirow[t]{2}{*}{$\mathrm{df}$} & \multirow{2}{*}{$\begin{array}{l}\text { Sig. (2- } \\
\text { taild) }\end{array}$} \\
\hline & & \multirow[t]{2}{*}{ Mean } & \multirow[t]{2}{*}{$\begin{array}{l}\text { Std. } \\
\text { Deviation }\end{array}$} & \multirow[t]{2}{*}{$\begin{array}{l}\text { Std. } \\
\text { Error } \\
\text { Mean }\end{array}$} & \multicolumn{2}{|c|}{$\begin{array}{l}95 \% \text { Confidence } \\
\text { Interval of the } \\
\text { Difference }\end{array}$} & & & \\
\hline & & & & & Lower & Upper & & & \\
\hline Pair1 & other - self & -.66240 & .69565 & .06694 & -.79510 & -.52971 & -9.896 & 107 & .000 \\
\hline
\end{tabular}

The means of factor 1 (other- regulation) and factor 2(self -regulation) are 3.2860 and 3.9484 respectively which indicates that Iranian EFL teachers tend to use factor 2 more in their professional development and rely more on their own experiences and capacities rather than external guide and support. The significance of the 2 factors' mean differences were also calculated using paired sample test. The result is reported in Table 11 .

Table 11

Paired sample test

\begin{tabular}{lllllc}
\hline & $\mathrm{N}$ & Minimum & Maximum & Mean & Std. Deviation \\
\hline Other & 108 & 1.00 & 4.78 & 3.2860 & .74469 \\
\hline Self & 108 & 1.29 & 5.00 & 3.9484 & .65348 \\
\hline Average & 108 & 3.84 & 9.49 & 7.2344 & 1.21625 \\
\hline Valid N (listwise) & 108 & & & &
\end{tabular}

The results confirmed that Iranian EFL teachers significantly use self- regulation factor more than other regulation factor. The difference between the means is significant at .000 value. 


\section{DISCUSSION}

Teachers' learning how to teach may begin in their pre-service teacher education but emerges and flourishes during their professional career. That's why this study is not limited to what teachers learn before they start to teach. Reviewing the relevant literature, it can be noticed that teachers' professional development has been the focus of many researchers (Avalos, 2011). Additionally, throughout the past decade, evaluating teachers' success has become an important concern due to the increased motivation on teacher accountability. As Miles, Odden, Fermanich, and Archibald (2014) mentioned, teachers need intense, high quality professional development to advance their instructional capability and that of the schools'. However, as Talebinezhad and Sadeghi Bennis (2005) asserted, not many of the programs designed have been successful in meeting teachers' needs. In fact, the critical factors needed to be considered are not well recognized by program developers.

Gathering data related teachers' professional development provides valuable information for future needed educational packages which can help in forming curriculum for major development. Therefore, a PD questionnaire was developed and administered to determine what factors Iranian EFL teachers use in their professional development process. Reliability analyses and factor analysis procedures led to the extraction of two factors from the scale: other regulation and self- regulation.

The findings illustrate that Iranian EFL teachers significantly use self- regulation more than other regulation which can be interpreted in two different ways:

1. As cited in Ellis (2003), Vygotsky (1978) used the metaphor of the zone of proximal development as a distance to explain the difference between an individual's actual and potential level of development. The beginning of this distance is characterized by what individuals can do by the help of others and the end of which is when they can perform independently. During this distance an individual becomes less and less reliant on scaffolding (learning by the help of others). The phenomenon does not seem to be different for teachers. They are expected to pass away a similar pathway. Thus, what can be interpreted from the results obtained is the respondents' (EFL teachers in Iran) reaching their potential level of development. It sounds the professional environment and community in Iran has provided the practitioners with appropriate conditions and mechanisms to shape their professional development.

2. One different interpretation, however, is that on one hand Iranian EFL teachers are not adequately trained and equipped to make effective use of other regulation factors and on the other in-service teacher training programs and workshops in Iran are not effective and attractive enough for language teachers. Part of the reason can also be traced back to cultural discrepancies of EFL and ESL situations. The first interpretation, however, seems more plausible to the researcher.

Related to the results of this study, Corburn (2016) used a mixed-method research to examine the professional development of a group of experienced primary school teachers who had taught English. He found that as teachers got more experienced, they became less dependent on textbooks, their confidence on oral English proficiency 
generally increased, and got more aware of deeper meanings of curriculum goals. Bransford, Burn, \& Cocking (2000, pp. 191-192) distinguished five different ways in which teachers learn and develop:

1) Teachers learn from their own practice.

2) Teachers learn through interactions with other teachers.

3) Teachers learn from teacher educators in their school, and in specific teacher enhancement projects.

4) Teachers enroll independently in graduate programs.

5) Teachers learn about teaching outside their formal professional work.

In a similar vein, Prenger, Poortman, \& Handelzaits (2017) conducted a study to explore the factors influencing teachers' professional development in 23 professional learning communities. The results showed that a shared goal. Leadership, structured activities and a collective focus on student results were the influential factors. Grangeat and Gray (2007) also investigated the ways in which teachers manage to improve their practice and develop professionally. The data came from 60 interviews. The results highlighted the effects of the organisation of collective work situations: Spurring exchanges amongst teachers and school partners appeared to be a main factor in this regard.

\section{Implications of the Study}

This study can have different theoretical and practical implications for an EFL context. The newly developed and validated questionnaire on Teachers' professional development can be used by other researchers in the field to find the factors that contribute to teachers' professional development. Policy makers and material developers can refer to this study by looking at the factors included in the questionnaire. Another implication of this study is a demand for a shift in teacher education programs in which more effective issues for teachers' professional development are included.

\section{CONCLUSION}

The results of the present study showed that Iranian EFL teachers in Iran tend to rely more on the self-regulation factor than other-regulation factor. Other-regulation refers to teachers' use or request for external sources of guide and support such as asking colleagues for help, peer coaching, in-service training programs, observers' feedback, classroom observation, attending workshops, and checking relevant articles in the journals. Self-regulation, on the other hand, refers to teachers' internal sources such as self-evaluation and reflection, their experiences inside classes, their learning experiences and their learners' feedback. This may be partly due to the nature of teacher education training programs in Iran in which factors such as research skills, materials design and production, and post-method pedagogic indicators are less dealt with. Part of the reason, however, can also be traced back to cultural issues, in a sense that teachers prefer to use their own individual sources rather than seek help from others. 


\section{Limitations and Recommended Future Studies}

As there are a number of factors which can singly or interactively affect the result of a special study, mentioning limitations can be useful for the future research studies. It was not possible for researcher to control teachers' gender and it can be included as a factor in the following studies. Because of the differences seen in the behaviour of males and females, different results may be obtained including them in a study. Moreover, there are different estimations for the number of the participants considered in a validation study. Of course, the more the number of participants, the more valid the results will be.

The researcher provides a number of recommendations which may be used for further studies. Another research can be conducted using qualitative data collection procedures such as interviewing teachers in order to realize their views toward the contributing factors to teachers' professional development. The material used in this study can be filled out considering gender and age differences. Furthermore, confirmatory factor analysis can be employed on the questionnaire used in this study to see if the results can be supported.

\section{REFERENCES}

Atay, D. (2006). Teachers' Professional Development: Partnership in Research. TESLEJ, $10(2), 1-15$.

Avalos, B. (2011). Teacher professional development in Teaching and Teacher Education over Ten Years. Teaching and Teacher Education, 27 (1), 10-20.

Bransford, J. D., Brown, A. L., \& Cocking, R.R. (2000). How People Learn: Brain, Mind, Experience, and School, Expanded Edition. National Academy Press. Washington, D.C.

Borg, S. (2006). Teacher cognition \& language education. London: Continuum.

Brown, D. (2002). English language teaching in the "Post-Method" era: Towards better diagnosis, treatment, assessment. In J. Richards \& W.A. Ren \& Ya (Eds.). Methodology in language teaching (pp. 9-18). Cambridge, England: Cambridge University Press.

Corburn, J. (2016). The professional development of English language teachers, investigating the design and impact of a national in-service EFL teacher education course. Unpublished Ph.D. dissertation. Hedmark University of Applied Sciences.

Cordingley, P. (2007). Continuing Professional Development (CPD): What do specialists do in CPD programs for which there is evidence of positive outcomes for pupils and teachers? Research Evidence in Education Library. London: EPPI-Centre, Social Science Research Unit, Institute of Education, University of London.

Desimone, L. M., Smith, T. M., \& Ueno, K. (2006). Are Teachers Who Need Sustained, Content-Focused Professional Development Getting it? An administrator's dilemma. Educational Administration Quarterly, 42, 179-216. 
Desimone, L. M., \& Stuckey, D. A. (2014). Sustaining teacher professional development. Handbook of professional development in education: Successful models and practices, preK-12 (pp. 467-482). New York, NY: Guilford.

Dörnyei, Z. (2010). Questionnaires in second language research: Construction, administration, Processing ( $2^{\text {nd }}$ ed.). New York: Routtledge.

Elbaz, F. (1983). Teacher thinking: A study of practical knowledge. London: Crown Helm.

Ellis, R. (2003). Task-based language learning \& teaching. China: Oxford University Press.

Evers, A. T., Kreijns, K., \& Van Der Heijden, B. I. J. M. (2016). The Design and Validation of an Instrument to Measure Teachers' Professional Development at Work, Studies in Continuing Education, 162-178.

Grangeat, M., \& Gray, P. (2007). Factors Influencing Teachers' Professional Competence Development. Journal of Vocational Education and Training, 59(4), 485501.

Guskey, T. R. (2000). Evaluating Professional Development: Thousand Oaks: Corwin Press.

Guskey, T. R., \& Yoon, K. S. (2009). What Works in Professional Development? Phi delta kappan, 90, 495-500. http://dx.doi.org/10.1177/003172170909000709.

Kaiser, H. F. (1960). The Application of Electronic Computers to Factor Analysis. Educational and Psychological Measurements, 20, 141-151.

Karimi, M. N. (2011). The Effects of Professional Development Initiatives on EFL Teachers' Degree of Self-Efficacy. Australian Journal of Teacher Education (Online), 36(6), 50-62.

Kumaravadivelu, B. (2012). Language teacher education for a global society: A modular model for knowing, analyzing, recognizing, doing, and seeing. New York: Routledge.

Miles, K. Odden, A. Fermanich, M., \& Archibald, S. (2004). Inside the Black Box of School District Depending on Professional Development: Lessons from Urban Districts. Journal of Educational Finance, 30, 1- 26.

Miller, J. (2006). Social Languages \& Schooling: The Uptake of sociocultural perspectives in schools', in Margaret Hawkins (ed.), Language Learning \& Teacher Education. (Clevedon Multilingual Matters), (pp.113-46).

Ninlawn, G. (2015). Factors which Affect Teachers' Professional Development in Teaching Innovation and Educational Technology in the $21^{\text {st }}$ Century under the Bureau of Special Education, Office of the Basic Education Commission. Social and Behavioral Sciences, 1732-1735.

Pallant, J. (2013). SPSS survival manual: A step by step guide to data analysis using SPSS-Open University Press. 
Prenger, R., Poortman, C. L., \& Handelzaits, A. (2017). Factors Influencing Teachers' Professional Development in Networked Professional Learning Communities. Teaching and Teacher Education, 68, 77-90.

Rastegar Haghighi Shirazi, Z., Bagheri, M. S., Sadighi, F., \& Yarmohammadi, L. (2015). Promoting Teachers' Professional Development: The Role of Individual and Contextual Factors. International Journal of Applied Linguistics and English Literature, 4(1), 41-49.

Richards, J. C. (2011). Competence \& Performance in Language Teaching. Cambridge University Press.

Richards, J. C., \& Farrell, T. S. C. (2005). Professional Development for Language Teachers: Strategies for Teacher Learning. Cambridge University Press, Cambridge.

Tabachnick, B. G., \& Fidell, L. S. (2007). Using Multivariate Statistics, Fifth Edition. Boston: Pearson Education, Inc.

Talebinezhad, M. R., Sadeghi Bennis, A. R. (2005). Non-academic L2 users: A Neglected Research Pool in ELT in Iran. Linguistic Online, 25(4), 85-96.

Yandell, J. (2017). Knowledge, English, and the Formation of Teachers. Pedagogy, Culture \& Society, 25, 583-599.

Yurtsever, G. (2013). English Language Instructors' Beliefs on Professional Development Models and Preferences to Improve Their Teaching Skills. ProcediaSocial and Behavioral Sciences, 70, 666-674

\section{APPENDIX}

\section{Professional Development Questionnaire}

Dear colleagues,

Please indicate the extent to which the following factors can affect the development of your professional skills as an EFL teacher according to the following continuum:

$0=$ not at all $5=$ completely

\begin{tabular}{|c|c|c|c|c|c|c|c|}
\hline \multirow[b]{2}{*}{ No } & \multirow[b]{2}{*}{ Factors } & \multicolumn{6}{|c|}{ Degree of effect } \\
\hline & & 0 & 1 & 2 & 3 & 4 & 5 \\
\hline 1 & The courses I pass at BA & & & & & & \\
\hline 2 & The courses I pass at MA & & & & & & \\
\hline 3 & Teaching experiences inside the classrooms & & & & & & \\
\hline 4 & In service teacher training programs (TTC) & & & & & & \\
\hline 5 & My own reflections on issues and challenges I have faced in the class & & & & & & \\
\hline 6 & Observers' feedbacks (comments and suggestions) & & & & & & \\
\hline 7 & Asking colleagues for help and support & & & & & & \\
\hline 8 & Checking relevant research findings in the journals & & & & & & \\
\hline 9 & Attending workshops and conferences & & & & & & \\
\hline 10 & My own experiences as a learner & & & & & & \\
\hline 11 & Institutional teaching tips, rules and regulations & & & & & & \\
\hline 12 & Materials and textbooks, I've taught & & & & & & \\
\hline 13 & Learners' feedback (suggestions and criticisms) & & & & & & \\
\hline 14 & Teachers' book & & & & & & \\
\hline 15 & Peer coaching & & & & & & \\
\hline 16 & Self-critical evaluation & & & & & & \\
\hline 17 & Classroom observation & & & & & & \\
\hline 18 & $\begin{array}{l}\text { Learners' overall attitude toward the nature and scope of classroom events and } \\
\text { activities }\end{array}$ & & & & & & \\
\hline
\end{tabular}

